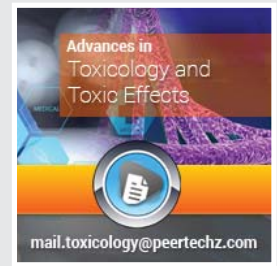

\section{Cytotoxic mechanism of}

\section{Bothrops jararaca venom}

\section{mediated by mitochondrial}

\section{depolarization}

\section{Ana Moira Morás ${ }^{1}$, Luiza Steffens ${ }^{1}$, Bruna Eliza Nordio', Jenifer Saffi', Eliane Dallegrave ${ }^{2}$, Luciana Grazziotin Rossato-Grando ${ }^{3}$ and Dinara Jaqueline Moura ${ }^{1 *}$}

${ }^{1}$ Laboratory of Toxicological Genetics, Federal University of Health Sciences of Porto Alegre, Porto Alegre, RS, Brazil

${ }^{2}$ Department of Pharmacosciences, Federal University of Health Sciences of Porto Alegre, Porto Alegre, RS, Brazil

${ }^{3}$ Graduate Program in Bioexperimentation, University of Passo Fundo, Passo Fundo, RS, Brazil
Received: 13 February, 2020

Accepted: 16 March, 2020

Published: 17 March, 2020

*Corresponding author: Dinara Jaqueline Moura, Laboratory of Toxicological Genetics, Federal University of Health Sciences of Porto Alegre, Rua Sarmento Leite, 245/Lab 714, 90050-170, Porto Alegre, RS, Brazil, Tel: +55 513303 8861; E-mail: dinaram@ufcspa.edu.br

Keywords: Bothrops jararaca venom; Mitochondrial damage; Oxidative stress; Cytotoxicity

https://www.peertechz.com

Check for updates

\title{
Abstract
}

Background: Snake venoms are natural sources of proteins and peptides with several biological activities. Therefore, this study aimed to evaluate the in vitro toxicity of crude Bothrops jararaca (B. jararaca) venom on different human tumor cells and investigate its action mechanism.

Material and methods: The crude venom from B. jararaca was provided by State Foundation for Health Research and Production and Center of Toxicological Information of Rio Grande do Sul, Brazil. To investigate different sensitivities of normal and cancer cell lines, cell viability was measured by using the MTT and neutral red uptake assays. Reactive oxygen species was measured by the oxidation of MitoSox probe by superoxide anion in the mitochondria. Transmembrane mitochondrial potential was evaluated using Mitostatus probe incorporation. Genotoxicity evaluation was carried out by using alkaline comet assay. The activity of antioxidant enzymes, superoxide dismutase and Catalase (CAT), was assessed by measuring adrenochrome formation and absorbance of $\mathrm{H}_{2} \mathrm{O}_{2}$, respectively. To access the oxidative potential of crude venom, the oxidation of dichloro-dihydro-fluorescein diacetate probe and the adrenochrome formation were measured after incubation with the venom.

Results: The acute treatment decreased in a dose-dependent manner the cell viability of HT-29, HCT116, MCF7 and HepG2 and the chronic exposition increased the cytotoxic effect $(p>0.05)$ significantly. No differences in DNA damage or superoxide anion generation were observed in MCF7 cells after treatment. However, the mitochondrial membrane potential decreased and catalase activity increased after treatment in MCF7 cell line, indicating that the venom cytotoxicity could be due to the intrinsic apoptosis pathway mediated by mitochondrial damage and oxidative stress. Thus $B$. jararaca venom exhibited antitumor mechanism related to mitochondrial damage. Moreover, $B$. jararaca venom presented an oxidative potential in vitro.

Conclusion: These results contribute to understand the mechanism of action and suggest that snake venoms are a useful source to search new drugs with potential applications in cancer therapy.

\section{Introduction}

Among species of venomous serpents, Bothrops jararaca (B. jararaca) belongs to the Viperidae family and it is present in southern and southeastern of Brazil, which is a significant cause of snakebite envenomation cases in the country $[1,2]$.
Bothrops snake venoms have more than $90 \%$ proteins with a large range of different biological activities [3]. For instance, it was shown that the crude venom of $B$. jararaca presents a wide spectrum of antibacterial activity, against gran-positive and gran-negative species, evidencing a great antibacterial potential of B. jararaca venom [4]. 
Metalloproteinases, proteinases, L-Amino Acid Oxidase (LAAO) and phospholipases A2 are the protein classes more abundant associated with clinical symptoms of intoxications $[5,6]$. The flavoenzyme LAAO catalyzes the oxidative deamination of $\mathrm{L}$-amino acids producing $\alpha$-keto acids, ammonia and hydrogen peroxide $\left(\mathrm{H}_{2} \mathrm{O}_{2}\right)$. This enzyme has attracted and regained the interest of researchers due to its cytotoxic, anti-microbial, anti-viral effects and tumor cell proliferation decrease. The LAAO functions were related directly with oxidative stress and $\mathrm{H}_{2} \mathrm{O}_{2}$ generation $[3,7,8]$.

The cancer treatment with greater selectivity and fewer side effects remains one of the most important challenges to medical research. Potential antitumor effect of bothropic venom was demonstrated by crude venom toxic effects to Ehrlich ascites tumor cells, in vitro and in vivo. These effects were associated with a decrease of inflammatory mediators IL10 , IL-6 and $\mathrm{TNF} \alpha[9,10]$. Jararhagin, a toxin of $B$. jararaca with Zn-dependent metalloproteinase activity, presents cytotoxic, anti-proliferative and anti-metastatic effects against murine melanoma cell by inducing the activation of caspase-3, leading to senescence and apoptosis $[11,12]$. The BJcuL, a lectin isolated from B. jararacussu venom, decreased colon adenocarcinoma cell viability in a dose-dependent manner and proliferation by inhibiting the proliferating cell nuclear antigen expression, affected the oxygen uptake and promoted cytochrome c release from mitochondria [13]. Likewise, other lectins from Bothrops genus already were associated with cytotoxic effects in tumor cells [14].

Owing to the complex mixture of proteins and peptides, it is well known that Bothrops venoms and toxins are especially intriguing and can be considered a promising natural source of molecules that have cytotoxic effects against tumor cells. However, the mechanism of this effect remains to be elucidated [15]. In this sense, this study aimed to evaluate the in vitro toxicity of crude $B$. jararaca venom on different human tumor cells, focusing on its mechanism of action.

\section{Material and methods}

\section{Material and venom acquisition}

Dulbecco's Eagle Medium (DMEM), Fetal Bovine Serum (FBS), trypsin-Ethylenediaminetetraacetic Acid (EDTA), L-glutamine, antibiotics (penicillin/streptomycin) were purchased from Gibco BRL (Grand Island, NY, USA). Methyl Methane Sulfonate (MMS), catalase, epinephrine and 3-(4,5-dimethyl-2-thiazolyl)-2,5-diphenyl-2-H-tetrazolium bromide (MTT) were purchased from Sigma-Aldrich (St. Louis, MO, USA). The $\mathrm{H}_{2} \mathrm{O}_{2}$ was purchased from Merck (Merck, Brazil). MitoSOX and Mitostatus were obtained from Invitrogen (Grand Island, NY, USA) and BD Biosciences (San Diego, CA, USA), respectively. All others reagents were of analytical grade. The crude venom from B. jararaca was provided by State Foundation for Health Research and Production (FEPPS) and Center of Toxicological Information of Rio Grande do Sul (CIT-RS) (Porto Alegre, RS, Brazil).

\section{Storage and protein quantification of $B$. jararaca venom}

Crude venom was lyophilized in order to prevent proteolysis and it was stored at $-20^{\circ} \mathrm{C}$. Protein amount was quantified by using Folin method [16]. Briefly, a standard curve was prepared by using a series of dilutions of bovine serum albumin. The samples were mixed with Lowry reagent, incubate at room temperature for 10min, then, mixed with Folin reagent and incubate for 30min. The absorbances were measured at $750 \mathrm{~nm}$ in a spectrophotometer microplate reader (Spectra Max M2, Molecular Devices, San Jose, USA). For the following experiments, the venom was diluted in ultrapure water, under laminar flow, and filtrated using a $0.2 \mu \mathrm{m}$ filter.

\section{Cell lines and culture conditions}

Epithelial cells (HEK293T), hepatocellular carcinoma cells (HepG2), colorectal adenocarcinoma cells (HT-29) and colorectal carcinoma cells (HTC116) were cultivated in Dulbecco's Modified Eagle's Medium (DMEM) supplemented with $10 \%$ of fetal bovine serum (FBS), 100units. $\mathrm{mL}^{-1}$ penicillin and $100 \mu \mathrm{g} . \mathrm{mL}^{-1}$ streptomycin. Cells of breast adenocarcinoma (MCF7) were cultured in RPMI 1640 medium. All cell lines were maintained in an incubator with a humidified atmosphere at $37^{\circ} \mathrm{C}$ with $5 \% \mathrm{CO}_{2}$ Cells were obtained from the American Type Culture Collection (ATCC) bank. All cultures were regularly tested to ensure the absence of mycoplasma.

\section{Screening of cytotoxic effect}

To investigate different sensitivities of cell lines, the viability was measured by using the MTT assay, as described previously, with some modifications [17]. Cells were seeded in 96 wells plates $\left(1 \times 10^{4}\right.$ cells/well) and exposed to different concentrations

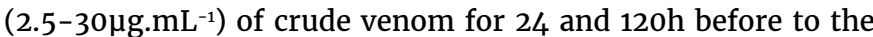
addition of MTT (0.33mg.mL ${ }^{-1}$ ) for three hours at $37^{\circ} \mathrm{C}$. After incubation, formazan crystals were solubilized in DMSO and absorbance was measured at 570nm in a spectrophotometer microplate reader (SpectraMax M2, Molecular Devices and San Jose, USA). The inhibitory concentration value $\left(\mathrm{IC}_{50}\right.$ ) was calculated with the equation of the line of viability curve. The Selectivity Index (SI) was calculated as the ratio between $\mathrm{IC}_{50}$ of normal cell line and $\mathrm{IC}_{50}$ of tumor cell line. SI $>3$ and $<6$ indicate moderate selectivity and SI $>6$ represents high selectivity [18].

\section{Neutral red assay}

The cytotoxicity of crude venom of $B$. jararaca was confirmed by using neutral red uptake assay, in accordance with a protocol previously described [19]. This assay is based on the incorporation of neutral red dye into lysosomes of viable cells. MCF7 were seeded in 96 wells plate $\left(1,6 \times 10^{4}\right.$ cells/well $)$ and exposed to different concentrations $\left(0.25-8 \mu \mathrm{g} \cdot \mathrm{mL}^{-1}\right)$ of crude venom for $120 \mathrm{~h}$. Then, cells were washed with PBS and incubated with $250 \mu \mathrm{L}$ of neutral red solution $\left(25 \mu \mathrm{g} . \mathrm{mL}^{-1}\right)$ at $37^{\circ} \mathrm{C}$ for three hours. After this, cells were washed and incubated for 3ominutes, protect of light, with adsorbent solution (acetic acid, ethanol and water, 1:50:49). Absorbance was measured at $540 \mathrm{~nm}$ in a spectrophotometer microplate reader (SpectraMax M2, Molecular Devices, San Jose, USA). 


\section{Measure of Reactive Oxygen Species (ROS)}

MitoSOX is a cell-permeable non-fluorescent probe that has an affinity to mitochondria and in the presence of superoxide anion is oxidized and emits fluorescence. MitoSOX assay was performed according to the manufacturer's specifications. Briefly, after treatment $\left(0.5-2 \mu \mathrm{g} \cdot \mathrm{mL}^{-1}\right)$, cells were incubated with MitoSOX solution for $10 \mathrm{~min}$ at $37^{\circ} \mathrm{C}$. Then, cells were washed and analyzed in FACs Calibur Cytometer (Becton Dickinson, San Jose, CA, USA). The Cell Quest software (Becton Dickinson, San Jose, CA, USA) was used to calculate the median fluorescence. Data were expressed as percentages of control, and 10,000 events were counted in each experiment.

\section{Determination of mitochondrial depolarization}

Mitostatus is a cell-permeable, cationic, fluorescent dye that is quickly sequestered by active mitochondria without inducing cytotoxic effects. The transmembrane mitochondrial potential was evaluated using Mitostatus incorporation according to the manufacturer's specifications. Briefly, after treatment

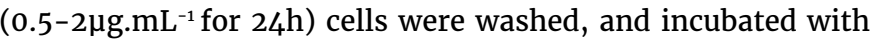
Mitostatus solution for $30 \mathrm{~min}$ in the dark at $37^{\circ} \mathrm{C}$. Then cells were washed and the fluorescence was measured using a FACSCalibur flow cytometer with Cell Quest software (Becton Dickinson, San Jose, CA, USA). A total of 10,000 events were measured per sample, and the percentage of mitochondrial depolarization was determined.

\section{Genotoxicity evaluation}

Alkaline comet assay was performed as described previously with minor modifications [20]. After treatment with different

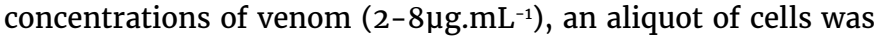
dissolved in $0.75 \%$ Low Melting Point Agarose (LMA), spread on agarose-precoated microscope slides and incubated in icecold lysis solution (2.5M NaCl, 100mM EDTA, 10mM, 1\% Triton $\mathrm{X}-100$ and $10 \%$ DMSO, $\mathrm{pH} 10.0$ ) for $24 \mathrm{~h}$ at $4^{\circ} \mathrm{C}$. Slides were incubated with an alkaline buffer in a horizontal electrophoresis chamber for 15 min (300mM NaOH and 1mM EDTA, pH 13.0). Electrophoresis was conducted at $4^{\circ} \mathrm{C}$ for $20 \mathrm{~min}$ with an electric current of $300 \mathrm{~mA}$, and $25 \mathrm{~V}$. Slides were then neutralized $(0.4 \mathrm{M}$ Tris, $\mathrm{pH}$ 7.5) and stained with silver nitrate. For the measure of DNA damage, 100 cells per slide were analyzed by optical microscopy. Cells were scored into five classes (0-4) according to relation tail-head. The Damage Index (DI) was calculated to each slide and ranges from 0 (no tail: 100 cells $\times 0$ ) to 400 (with maximum migration: 100 cells $\times 4$ ).

\section{Determination of superoxide dismutase (SOD) and cata- lase (CAT) activities}

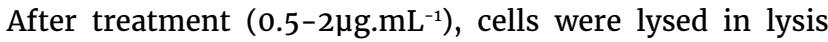
buffer [50mM Tris-HCl, 200mM NaCl, 1mM EDTA, 1\% DMSO, $1 \mathrm{mM}$ PMSF, plus protease inhibitors EDTA-free tablets (Roche)]. The cellular extract was used for the determination of SOD and CAT activities. SOD activity was evaluated by quantifying the inhibition of superoxide-dependent autoxidation of epinephrine, verifying the absorbance of the samples at $480 \mathrm{~nm}$ [21]. Cells were mixed with glycine buffer (50mM, pH10.2), catalase $(10 \mathrm{mM})$ and epinephrine $(60 \mathrm{mM})$. Then, absorbance was immediately recorded each $36 \mathrm{~s}$ for $15 \mathrm{~min}$ at $480 \mathrm{~nm}$ in SpectraMax $\mathrm{M}^{2 \mathrm{e}}$ Microplate Reader (Molecular Devices, San Jose, USA). One SOD unit is defined as the amount of SOD necessary to inhibit $50 \%$ of epinephrine autoxidation and the specific activity is reported as SOD Units/mg protein. The CAT activity was assayed according to the method described by Aebi [22], based on the decrease in absorbance of $\mathrm{H}_{2} \mathrm{O}_{2}$ at $240 \mathrm{~nm}$. Briefly, each sample aliquot was added to potassium phosphate buffer (20mM, pH 7.2). Subsequently, $\mathrm{H}_{2} \mathrm{O}_{2}$ (10mM) was added, and the absorbance was immediately recorded each $36 \mathrm{~s}$ for 5 min at 240nm using SpectraMax $\mathrm{M}^{2 \mathrm{e}}$ Microplate Reader (Molecular Devices, San Jose, USA). One CAT unit is defined as one $\mu \mathrm{mol}$ of $\mathrm{H}_{2} \mathrm{O}_{2}$ consumed per minute and the specific activity is calculated as CAT Units/mg protein.

\section{Determination of the venom oxidative potential}

To access the oxidative potential of $B$. jararaca crude venom, two methodologies were used. Firstly, the crude venom or a $5 \mathrm{x}$ dilution of the venom in distillated $\mathrm{H}_{2} \mathrm{O}$ were incubated with dichloro-dihydro-fluorescein diacetate (DCFH-DA). This method is based on the deacetylation of DCFH-DA probe and its subsequent oxidation by reactive oxygen species into a fluorescent compound: 2', 7'-dichlorofluorescein (DCF).

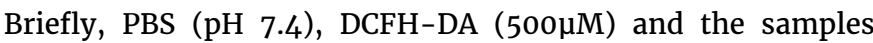
were incubated in a 96 -well dark-plates at $37^{\circ} \mathrm{C}$ for $30 \mathrm{~min}$. Fluorescence was recorded with a SpectraMax $\mathrm{M}^{2 \mathrm{e}}$ Microplate Reader (Molecular Devices, San Jose, USA) and the excitation and emission wavelengths were set as $490 \mathrm{~nm}$ and $525 \mathrm{~nm}$, respectively. Subsequently, a series of dilutions of the crude venom were incubated with adrenaline $(2 \mathrm{mM})$ to evaluate the venom potential in accelerate the adrenochrome formation after adrenaline auto-oxidation. Succinctly, glycine buffer $(\mathrm{pH}$ $10.2,50 \mathrm{mM})$, catalase $\left(100 \mathrm{U} . \mathrm{mL}^{-1}\right)$, and the test solutions were incubated in a 96-well plate. After the addition of adrenaline, the adrenochrome formation was monitored at $480 \mathrm{~nm}$ at $32^{\circ} \mathrm{C}$ for $15 \mathrm{~min}$. For comparison purposes, a negative control was analyzed without addition of the crude venom. The results were normalized with the total amount of protein.

\section{Statistical analysis}

All experiments were independently repeated at least three times. Results are expressed as mean \pm standard error of the mean (SEM). Data were analyzed by one-way or two-way analysis of variance (ANOVA), and means were compared using Dunnett's Multiple Comparison or Bonferroni's Test Multiple Comparison, with $P<0.05$ considered as statistically significant.

\section{Results}

\section{Cytotoxicity profile of crude venom in tumor cell lines}

To evaluate the cytotoxic ability of B. jararaca crude venom, tumor and normal epithelial cell lines were analyzed by using MTT assay. The treatment was performed at 24 and $120 \mathrm{~h}$ to simulate an acute and chronic condition, respectively. Our results showed that $B$. jararaca venom was highly cytotoxic on all cell lines and a dose-dependent profile. Besides that, cells were more sensitive to chronic exposition, evidenced 
by the reduction of $\mathrm{IC}_{50}$ values (Figure $1 \mathrm{~A}-\mathrm{E}$ ). No significant differences between 24 and $120 \mathrm{~h}$ were found in the HepG2 cell line treatment. Interestingly, the breast cancer cell line, MCF7, was more sensitive than the normal cell line, HEK293T, in a chronic treatment at 2.5 and $5 \mu \mathrm{g} . \mathrm{mL}^{-1}$, showing moderate selectivity in these conditions (IS $>3$ and $<6$; Figure $1 \mathrm{~F}$ ). The $\mathrm{IC}_{50}$ was found to be $8.69 \mu \mathrm{g} \cdot \mathrm{mL}^{-1}$ in HEK293 T and $2.80 \mu \mathrm{g} . \mathrm{mL}^{-1}$ in MCF7 after $12 \mathrm{oh}$ of exposition to the venom. The next step was to evaluate the venom's mechanism of action in the MCF7 cell line owing to the selectivity that the venom showed in this cell line. The concentrations used in the next assays were around the $\mathrm{IC}_{50}$ in MCF7 after $120 \mathrm{~h}$ of exposure.

\section{Absence of DNA breaks after treatment with crude ve- nom}

Genotoxicity was tested through comet assay aiming to investigate if the cytotoxicity induced by the venom could be mediated by DNA damage. Comet assay is a robust and sensitive method to measure single and double strand breaks in DNA in individual cells. The results showed that neither in $24 \mathrm{~h}$ (Figure $2 \mathrm{~A}$ ) nor in $48 \mathrm{~h}$ (Figure $2 \mathrm{~B}$ ) crude venom induced breaks in DNA at the tested concentrations. The viability curve presented a linear profile, supporting that the dose of $8 \mu \mathrm{g} \cdot \mathrm{mL}^{-1}$ would already induce cytotoxic effects after $24 \mathrm{~h}$. Despite this, DNA damage was not observed.
A

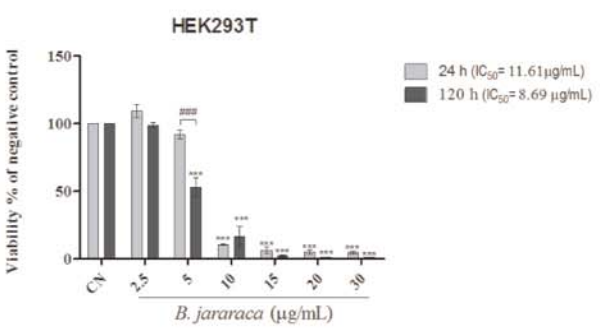

C

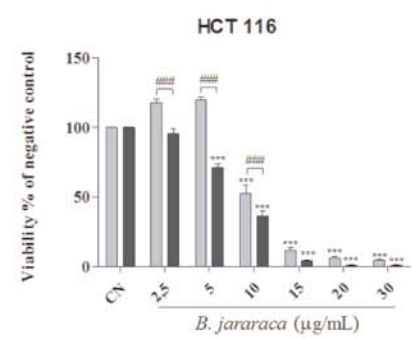

$\mathbf{E}$

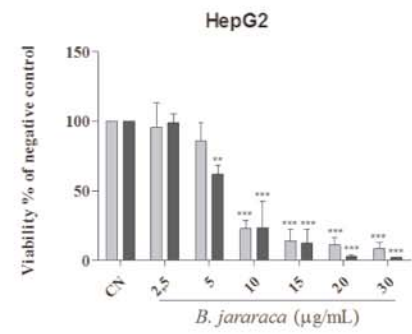

B

HEK293T MCF7

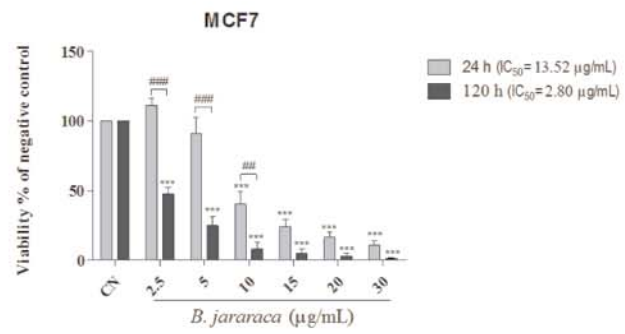

D

HCT 116

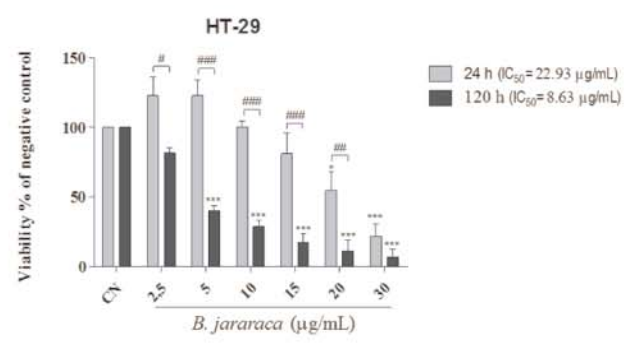

HT-29

$\mathbf{F}$

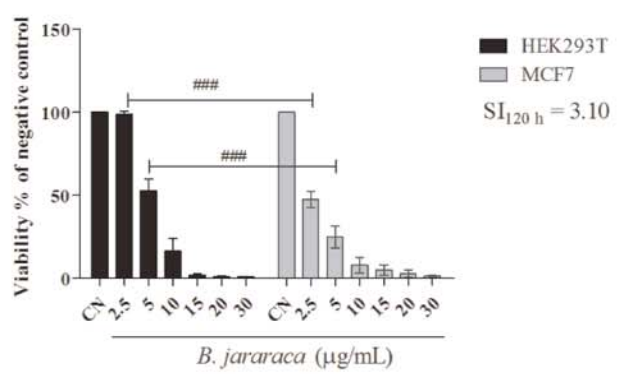

Figure 1: Crude venom from B. jararaca decrease cell viability. Cell viability after 24 and $120 \mathrm{~h}$ of treatment with crude venom of Bothrops jararaca, by MTT assay. (A) Normal cell line. (B - E) Tumor cell lines. (F) Cell viability of HEK293T and MCF7 after $120 \mathrm{~h}$. Selectivity Index was shown to $120 \mathrm{~h}$ of treatment. Results are expressed as mean percentage of negative control \pm SEM. *Significant difference comparing each concentration to negative control treatment at $P<0.05 ; \star \star * P<0.01$; $* \star \star P<0.001 / 0$ ne-way ANOVA/ Dunnett's Multiple Comparison Test. \#Significant difference compared both times in each concentration at $\mathrm{P}<0.05 ; \# \# \mathrm{P}<0.01 ; \# \# \# \mathrm{P}<0.001 / \mathrm{Two}-\mathrm{way}$ ANOVA/ Bonferroni's Multiple Comparison Test. 


\section{Crude snake venom induces mitochondrial damage}

Mitostatus assay was used to evaluate if the crude venom would be inducing toxicity by damaging the mitochondrial membrane potential. Results showed that crude snake venom induces depolarization of the mitochondrial membrane in a dose-dependent manner (Figure 3A). This result was very interesting since the evaluations were performed using sub-lethal doses and acute treatment time, indicating that accumulated mitochondrial damage could be the cause of cell death, mainly intrinsic apoptosis pathway, as evidenced by another research [23].

\section{Oxidative stress induced by crude snake venom}

Given that some compounds present in Bothrops snake venom are oxidants, the generation of superoxide anion after $24 \mathrm{~h}$ of treatment with sub-lethal concentrations was measured. As shown in Figure 3B, no differences were observed between negative control and treatment groups in MCF7 cell line.

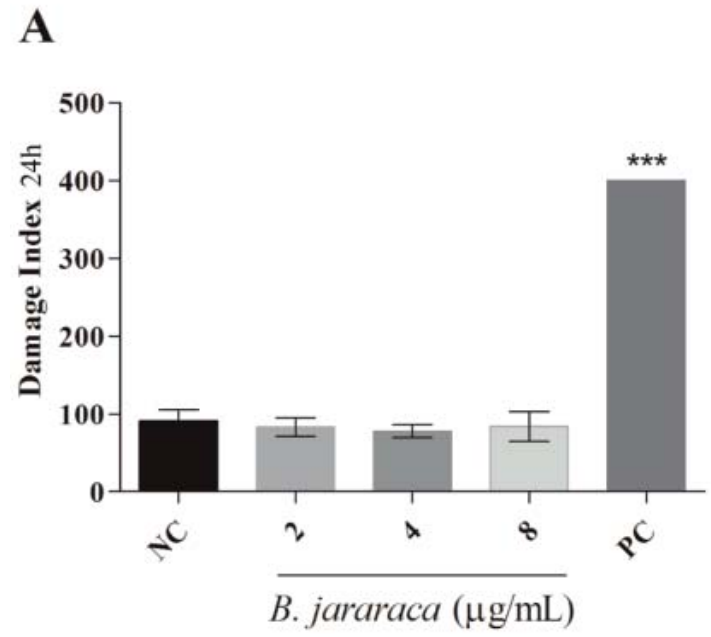

B

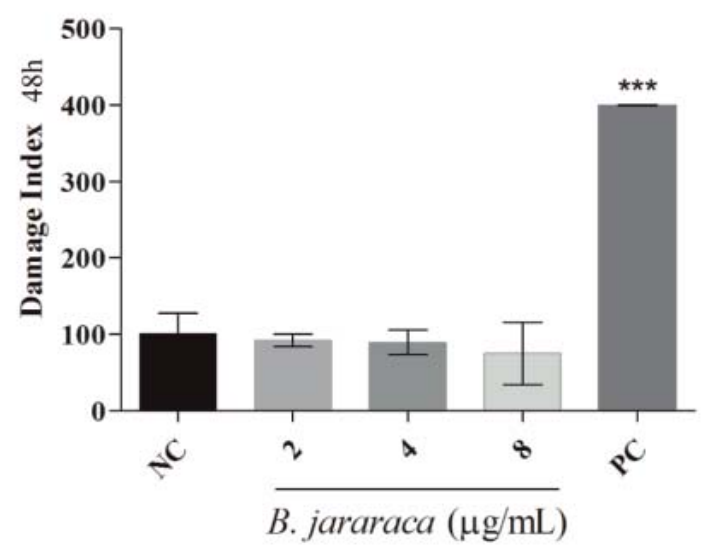

Figure 2: Crude venom from $B$. jararaca no increase DNA strand breaks in MCF7 cell line. DNA damage measure of MCF7 cell line, after 24h (A) and 48h (B) of treatment with crude venom of Bothrops jararaca, by comet assay. MMS $(0.1 \% / 1 \mathrm{~h})$ was used as positive control. Results are expressed as mean percentage of negative control \pm SEM. *Significant difference as compared to negative control at $P<0.05$; **P<0.01; ***P<0.001/One-way ANOVA/ Dunnett's Multiple Comparison Test.
A
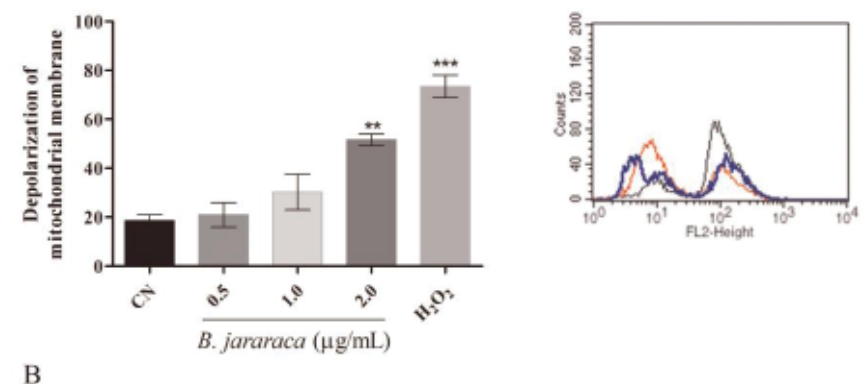

B
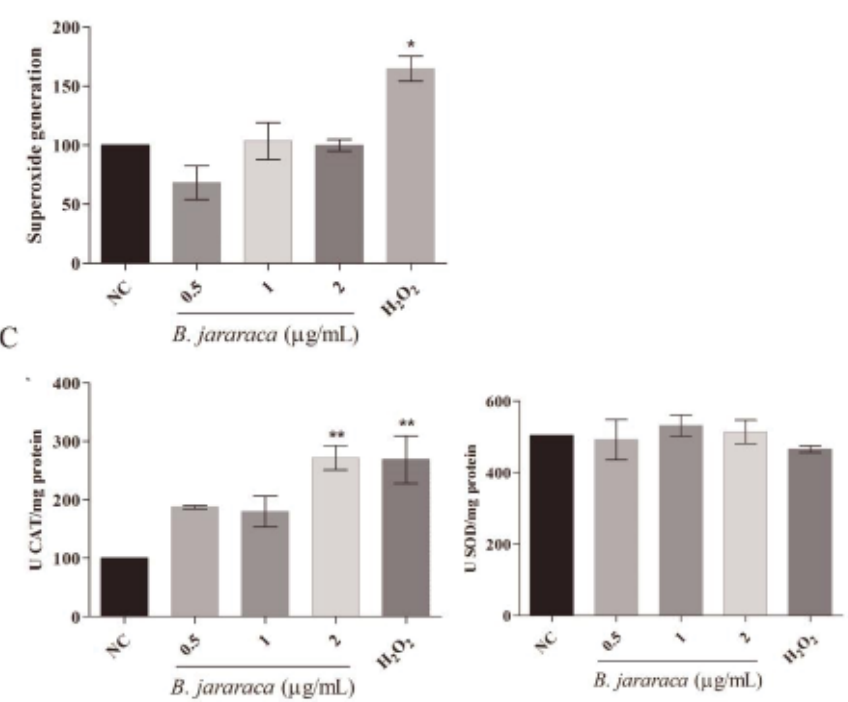

Figure 3: Crude venom from $B$. jararaca increases depolarization of mitochondrial membrane and catalase activity but no affects neither superoxide generation nor superoxide dismutase activity in MCF7 cell line. A- Percentage of cell with depolarization of mitochondrial membrane in MCF7 cells, after $24 \mathrm{~h}$ of treatment with crude venom of Bothrops jararaca, by Mitostatus assay. $\mathrm{H}_{2} \mathrm{O}_{2}(1 \mathrm{mM} / 1 \mathrm{~h})$ was used as positive control. At the top right corner shown a representative histogram as measured of Mitostatus cell incorporation. In detail the overlay of negative control (blue), positive control (black) and $2 \mu \mathrm{g} \cdot \mathrm{mL}^{-1}$ treatment (red). B - Levels of superoxide anion in mitochondria of MCF7 cells, after 24h of treatment with crude venom. $\mathrm{H}_{2} \mathrm{O}_{2}$ $(1 \mathrm{mM} / 1 \mathrm{~h})$ was used as positive control. C- Activity of Catalase and Superoxide dismutase in MCF7 extract, after 24h of treatment with brute venom of Bothrops jararaca. $\mathrm{H}_{2} \mathrm{O}_{2}(1 \mathrm{mM} / 1 \mathrm{~h})$ was used as positive control. Results are expressed as mean \pm SEM. *Significant difference as compared to negative control at $\mathrm{P}<0.05$; **P<0.01; ***P<0.001/One-way ANOVA/ Dunnett's Multiple Comparison Test.

To explore the consequences of mitochondrial damage and verify if oxidative stress could be involved in cell death, we evaluated the activity of CAT and SOD enzymes related to detoxification of oxygen reactive species. No differences were observed in SOD activity (Figure $3 \mathrm{C}$ ), as well as, in the results of MitoSOX assay (Figure 3B). However, CAT activity increased at the same concentration that affected the mitochondrial membrane potential (Figure $3 \mathrm{C}$ ).

\section{Neutral red assay confirms sensibility to crude snake venom}

MTT is a tetrazolium salt metabolized by mitochondria in formazan crystals. Thus, this assay may show a false positive response since the viability is measured indirectly by mitochondrial function. As we showed changes in mitochondrial membrane potential, our results of cytotoxic 
activity of crude venom were confirmed at $120 \mathrm{~h}$ by Neutral Red assay, a probe that is incorporated by the lysosomes. The results showed in Figure 4 confirm that crude venom is cytotoxic at low concentrations. The $\mathrm{IC}_{50}$ found in the Neutral Red assay

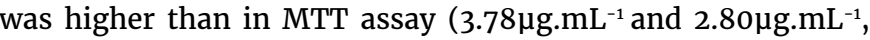
respectively) corroborating our hypothesis that mitochondrial damage is the main mechanism of action of crude venom from B. jararaca.

\section{Oxidant potential of crude venom in vitro}

Aiming to analyze the oxidant potential of the venom, the crude venom samples were incubated with DCFH-DA; therefore, the oxidation of this probe could be investigated by the measurement of DCF compound. Figure $5 \mathrm{~A}$ indicates that the DCF fluorescence formation was higher after DCFHDA incubation with the pure venom when compared to its $5 \times$ dilution. To confirm the venom's oxidative potential, the adrenaline oxidation was measured after incubation with a series of venom's dilutions, and the adrenochrome formation was recorded. The results (Figure $5 \mathrm{~B}$ ) show that the adrenaline oxidation decreases with the increased of dilutions and when compared to the negative control (sample without venom) the adrenochrome formation was higher, indicating an oxidative potential of the crude venom.

\section{Discussion}

The present study demonstrated the induction of cytotoxicity by $B$. jararaca crude venom in several tumor cell lines, with a moderate selective effect in MCF7 cell line (Figure 1). The MTT results indicate that crude venom significantly impacts on cell survival in a dose-dependent manner. The viability decreases significantly with a chronic exposure indicating a time-dependent effect. For instance, MCF7 cell line showed an increase of five times in the $\mathrm{IC}_{50}$ at chronic treatment compared with acute exposure. Tumor cytotoxicity of compounds from venom's snakes already was reported in MCF7 [24], HT-29

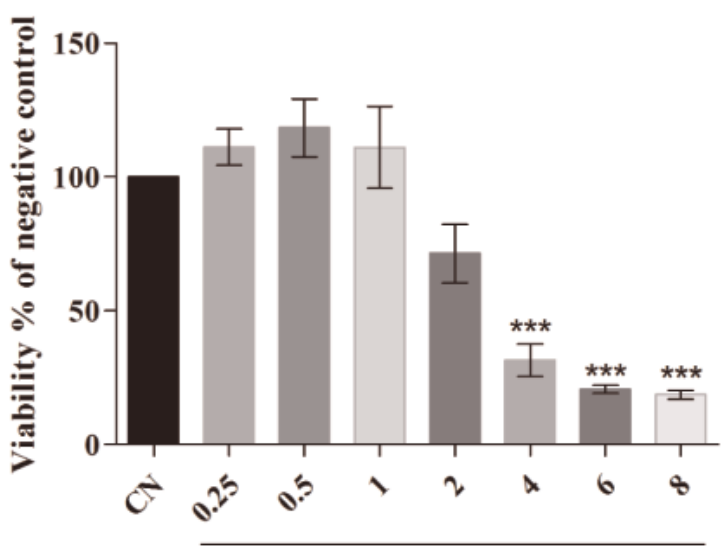

B. jararaca $(\mu \mathrm{g} / \mathrm{mL})$

Figure 4: Crude venom from $B$. jararaca decrease cell viability of MCF7 cell line. Cell viability of MCF7 cell line, after $120 \mathrm{~h}$ of treatment with brute venom of Bothrops jararaca, by Neutral Red assay. IC50 in this experimental conditions was $3.78 \mu \mathrm{g}$. $\mathrm{mL}^{-1}$. Results were expressed as mean percentage of negative control \pm SEM. * Significant difference as compared to negative control treatment at $\mathrm{P}<0.05$; **P $<0.01 ; * * * \mathrm{P}<0.001 /$ One-way ANOVA/ Dunnett's Multiple Comparison Test."
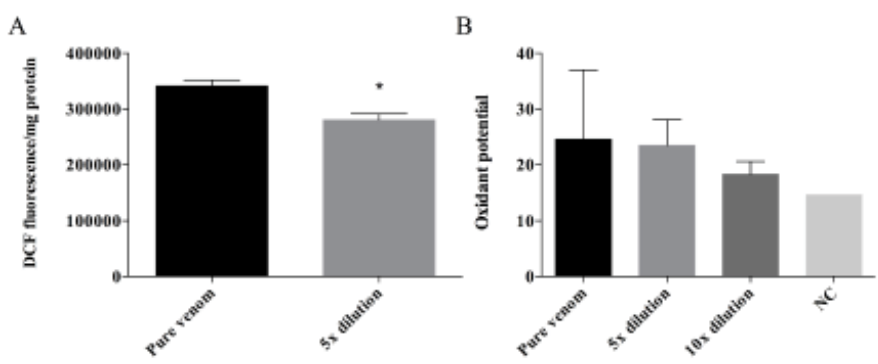

Figure 5: Crude venom from B. jararaca presents an oxidative potential. $A$ Crude venom was incubated with DCFH-DA and its oxidation product, DCF, was measured. B - Adrenaline oxidation was evaluated by adrenochrome formation after incubation with the venom

and HCT 116 cell lines [25]. Commonly, cell death by antitumor compounds is mediated by direct or indirect DNA damage $[26,27]$. Nevertheless, this outcome was not observed in the crude venom from $B$. jararaca, neither in $24 \mathrm{~h}$ nor in $48 \mathrm{~h}$ of treatment (Figure 2). Recently it was described that crude venom from $B$. jararaca and B. erythromelas exhibited a cytotoxic effect promoting cell cycle arrest and inducing apoptosis through mitochondrial depolarization in cervical cancer cells [23]. Mitochondrial damage is related to intrinsic apoptosis pathway activation by cytochrome c release and caspase cascade, mediated production of hydrogen peroxide [13]. Alves, et al. [28], also evidenced that LAAO isolated from B. atrox activates apoptosis intrinsic pathway with a cascade of caspase initiated by mitochondrial pathway and Klein, et al. [29], showed that Jararhagin increased expression of cell-cycle and apoptosisrelated genes, as $\mathrm{CASP}_{3}$ and $\mathrm{TP}_{53}$. Our results showed that the crude venom induced mitochondrial membrane depolarization (Figure 3A) and, consequently, increased the catalase activity (Figure $3 \mathrm{C}$ ) in acute exposure of sub-lethal doses, suggesting this effect as the initial toxic mechanism. The oxidative damage seems to be caused by the generation of $\mathrm{H}_{2} \mathrm{O}_{2}$, mainly substrate of catalase since the activity of superoxide dismutase activity and levels of anion superoxide were not altered (Figure 3B-C). To verify the hypothesis of ROS generation by the venom, the oxidative potential of the crude venom was analyzed (Figure 5) and the results indicate an oxidative mechanism induced by the venom that possibly is related to the oxidative damage induced by the samples into the cells. Therefore, our results suggest that the mechanism of cytotoxicity induced by crude venom (Figure 6) is through impaired mitochondrial function and generation of oxidative stress.

\section{Conclusion}

B. jararaca snake venom exhibits antitumor action related to mitochondrial damage, and the increase of catalase activity suggests that oxidative stress could be associated with this process by the generation of $\mathrm{H}_{2} \mathrm{O}_{2}$ caused by the oxidative deamination of L-amino acids by LAAO. The next steps involve evaluating whether crude venom directly affects the mitochondrial status or whether it is mediated by secondary pathways. In addition, the role of $\mathrm{H}_{2} \mathrm{O}_{2}$ should be better understood for correlated cytotoxicity effect with venom composition. Our results confirmed crude venom from $B$. jararaca as a potent source to investigate new drugs with potential applications in cancer therapy. 


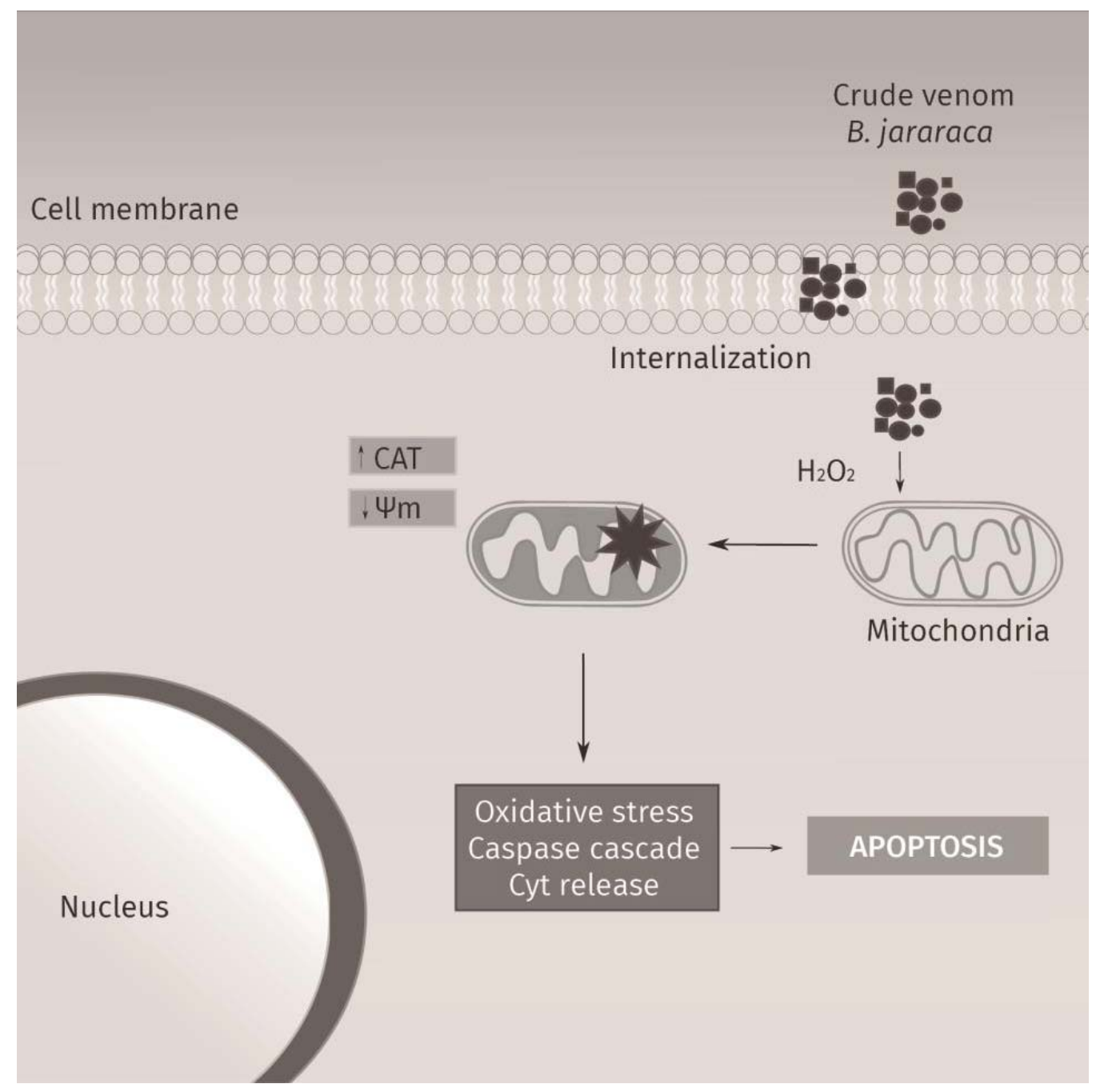

Figure 6: Representative mechanism of crude venom from B. jararaca. A complex mix of protein and peptides acting in mitochondrial function promoting decrease of mitochondria membrane potential and induced the $\mathrm{H}_{2} \mathrm{O}_{2}$ production. This damage promotes oxidative stress, activate intrinsic apoptosis pathway by cytochrome $\mathrm{c}$ release and activated caspase cascade

\section{Acknowledgments}

Research was supported by grants from CNPq (Conselho Nacional de Desenvolvimento Científico e Tecnológico, Brazil), FAPERGS (Fundação de Amparo à Pesquisa do Rio Grande do Sul) and CAPES (Coordenação de Aperfeiçoamento de Pessoal de Nível Superior).

\section{References}

1. Grazziotin FG, Monzel M, Echeverrigaray S, Bonatto SL (2006) Phylogeography of the Bothrops Jararaca Complex (Serpentes: Viperidae): Past Fragmentation and Island Colonization in the Brazilian Atlantic Forest. Mol Ecol 15: 39693982. Link: https://bit.ly/2x4FMzd

2. Stuqui B, De Paula-Silva M, Carlos CP, Ullah A, Arni RK, et al. (2015) Ac2-26 Mimetic Peptide of Annexin A1 Inhibits Local and Systemic Inflammatory Processes Induced By Bothrops Moojeni Venom and The Lys-49 Phospholipase A2 In A Rat Model. Plos One 10: E0130803. Link: https://bit.ly/2U9UQnd

3. Morais IC, Pereira GJ, Orzáez M, Jorge RJ, Bincoletto C, et al. (2015) L-Aminoacid Oxidase from Bothrops Leucurus Venom Induces Nephrotoxicity Via Apoptosis and Necrosis. Plos One 10: E0132569. Link: https://bit.ly/3b08aBw
4. Cendron LH, Bertol CD, Fuentefria DB, Calegari EM, Dallegrave E, et al. (2014) Broad Antibacterial Activity of Bothrops Jararaca Venom Against Bacterial Clinical Isolates. Adv Microbiol 4: 1174-1187. Link: https://bit.ly/2wW9XJ9

5. Sousa LF, Nicolau CA, Peixoto PS, Bernardoni JL, Oliveira SS, et al. (2013) Comparison of Phylogeny, Venom Composition and Neutralization by Antivenom in Diverse Species of Bothrops Complex. Plos Negl Trop Dis 7: E2442. Link: https://bit.ly/39Uliqn

6. Grazziotin FG, Monzel M, Echeverrigaray S, Bonatto SL (2012) Tumor Cytotoxicity of Leucurolysin-B, A P-lii Snake Venom Metalloproteinase from Bothrops Leucurus. J Venom Anim Toxins Incl Trop Dis 18: 24-33. Link: https://bit.ly/2w1gulK

7. Zhang H, Yang Q, Sun M, Teng M, Niu L (2004) Hydrogen Peroxide Produced by Two Amino Acid Oxidases Mediates Antibacterial Actions. J Microbiol 42: 336-339. Link: https://bit.ly/2Ub4kyp

8. Guo C, Liu S, Yao Y, Zhang Q, Sun MZ (2012) Past Decade Study of Snake Venom L-Amino Acid Oxidase. Toxicon 60: 302-311. Link: https://bit.ly/3aXukEd

9. Da Silva RJ, Da Silva MG, Vilela LC, Fecchio D (2002) Cytokine Profile of Ehrlich Ascites Tumor Treated with Bothrops Jararaca Venom. Mediators Inflamm 11: 197-201. Link: https://bit.ly/2WixPRC 
10. De Vieira Santos MM, Da Silva RJ, Da Silva MG, Fecchio D (2004) Subpopulations of Mononuclear Leukocytes Associated with Inhibition of Ehrlich Ascites Tumor Growth By Treatment With Bothrops Jararaca Venom Mediators Inflamm 13: 29-32. Link: https://bit.ly/2wbZXev

11. Maria DA, Da Silva MG, Correia MC, Ruiz IR (2014) Antiproliferative Effect of the Jararhagin Toxin on B16f10 Murine Melanoma. Bmc Complement Altern Med 14: 446. Link: https://bit.ly/2U7rQwk

12. Corrêa MC, Maria DA, Moura-Da-Silva AM, Pizzocaro KF, Ruiz IR (2002) Inhibition of Melanoma Cells Tumorigenicity by the Snake Venom Toxin Jararhagin. Toxicon 40: 739-748. Link: https://bit.ly/2Qi05jJ

13. Damasio Dde C, Nolte S, Polak LP, Brandt AP, Bonan NB, et al. (2014) The Lectin Bjcul Induces Apoptosis Through Trail Expression, Caspase Cascade Activation and Mitochondrial Membrane Permeability in A Human Colon Adenocarcinoma Cell Line. Toxicon 90: 299-307. Link: https://bit.ly/2TRIsta

14. Nunes ES, Souza MA, Vaz AF, Silva TG, Aguiar JS, et al. (2012) Cytotoxic Effect and Apoptosis Induction by Bothrops Leucurus Venom Lectin on Tumor Cell Lines. Toxicon 59: 667-671. Link: https://bit.ly/2INIBbF

15. Vyas VK, Brahmbhatt K, Bhatt H, Parmar U (2013) Therapeutic Potential of Snake Venom in Cancer Therapy: Current Perspectives. Asian Pac J Trop Biomed 3: 156-162. Link: https://bit.ly/3a6iGH2

16. Lowry OH, Rosebrough NJ, Farr AL, Randall RJ (1951) Protein measurement with the folin phenol reagente. J Biol Chem 193: 265-275. Link: https://bit.ly/38YbtaF

17. Mosmann T (1983) Rapid Colorimetric Assay for Cellular Growth and Survival: Application to Proliferation and Cytotoxicity Assays. J Immunol Methods 65 55-63. Link: https://bit.ly/2IOwzxL

18. Acton EM, Narayanan VL, Risbood PA, Shoemaker RH, Vistica DT, et al. (1994) Anticancer Specificity of Some Ellipticinium Salts Against Human Brain Tumors In Vitro. J Med Chem 37: 2185-2189. Link: https://bit.ly/2xIGdjd

19. The National Toxicology Program (NTP) and Interagency Center for the Evaluation of Alternative Toxicological Methods (NICEATM). A Test for Basal Cytotoxicity for an In Vitro Validation Study 2003. Link: https://bit.ly/2ISa4YR

20. Tice RR, Agurell E, Anderson D, Burlinson B, Hartmann A, et al. (2000) Single
Cell Gel/Comet Assay: Guidelines for In Vitro and In Vivo Genetic Toxicology Testing. Environ Mol Mutagen 35: 206-221. Link: https://bit.ly/3a6jBqY

21. Misra HP, Fridovich I (1972) The Role of Superoxide Anion in The Autoxidation Of Epinephrine and A Simple Assay for Superoxide Dismutase. J Biol Chem 247: 3170-3175. Link: https://bit.ly/2Ub6JJr

22. Aebi H (1994) Catalase in Vitro. Meth Enzymol 105: 121-126. Link: https://bit.ly/2U8An29

23. Bernardes-Oliveira E, Gomes DL, Martelli Palomino G, Juvenal Silva Farias K da Silva WD, et al. (2016) Bothrops Jararaca and Bothrops Erythromelas Snake Venoms Promote Cell Cycle Arrest and Induce Apoptosis Via the Mitochondrial Depolarization of Cervical Cancer Cells. Evid Based Complement Alternat Med 2016: 1574971. Link: https://bit.ly/2UdUVpS

24. Ebrahim K, Shirazi FH, Vatanpour $H$, Zare A, Kobarfard F, et al. (2014) Anticancer Activity of Cobra Venom Polypeptide, Cytotoxin-li, Against Human Breast Adenocarcinoma Cell Line (Mcf-7) Via The Induction of Apoptosis. J Breast Cancer 4: 314-322. Link: https://bit.ly/2UdVhwl

25. Zakraoui O, Marcinkiewicz C, Aloui Z, Othman H, Grépin R, et al. (2016) Lebein, A Snake Venom Disintegrin, Suppresses Human Colon Cancer Cells Proliferation and Tumor-Induced Angiogenesis Through Cell Cycle Arrest, Apoptosis Induction and Inhibition of Vegf Expression. Molecular Carcinogenesis 56: 18-35. Link: https://bit.ly/2WoeoH0

26. Rezaee M, Sanche L, Hunting DJ (2013) Cisplatin Enhances the Formation of DNA Single- And Double-Strand Breaks By Hydrated Electrons And Hydroxy Radicals. Radiat Res 179: 323-331. Link: https://bit.ly/2WiEbAG

27. Annovazzi L, Caldera V, Mellai M, Riganti C, Battaglia L, et al. (2015) The DNA Damage/Repair Cascade in Glioblastoma Cell Lines After Chemotherapeutic Agent Treatment. Int J Oncol 46: 2299-2308. Link: https://bit.ly/2TSOo4X

28. Alves RM, Antonucci GA, Paiva HH, Cintra AC, Franco JJ, et al. (2008) Evidence of Caspase-Mediated Apoptosis Induced by L-Amino Acid Oxidase Isolated from Bothrops Atrox Snake Venom. Comp Biochem Physiol A Mol Integr Physiol 151: 542-550. Link: https://bit.ly/2Qg2gnK

29. Klein A, Capitanio JS, Maria DA, Ruiz IR (2011) Gene Expression in Sk-Mel-28 Human Melanoma Cells Treated with the Snake Venom Jararhagin. Toxicon 57: 1-8. Link: https://bit.ly/38UA1BA
Discover a bigger Impact and Visibility of your article publication with

Peertechz Publications
Highlights

* Signatory publisher of ORCID

* Signatory Publisher of DORA (San Francisco Declaration on Research Assessment)

- Articles archived in worlds' renowned service providers such as Portico, CNKI, AGRIS, TDNet, Base (Bielefeld University Library), CrossRef, Scilit, J-Gate etc.

* Journals indexed in ICMJE, SHERPA/ROMEO, Google Scholar etc.

* OAI-PMH (Open Archives Initiative Protocol for Metadata Harvesting)

- Dedicated Editorial Board for every journal

- Accurate and rapid peer-review process

Increased citations of published articles through promotions

* Reduced timeline for article publication

Submit your articles and experience a new surge in publication services (https://www.peertechz.com/submission).

Copyright: () 2020 Morás AM, et al. This is an open-access article distributed under the terms of the Creative Commons Attribution License, which permits unrestricted use distribution, and reproduction in any medium, provided the original author and source are credited.

Citation: Morás AM, Steffens L, Nordio BE, Saffi J, Moura DJ, et al. (2020) Cytotoxic mechanism of Bothrops jararaca venom mediated by mitochondrial depolarization. Adv Toxicol Toxic Effects 4(1): 001-008. DOI: https://dx.doi.org/10.17352/atte.000007 